\title{
Impact of VUCA Environment in Practice of Rural Tourism
}

\author{
Eva ŠIMKOVÁ* and Martina HOFFMANNOVÁ \\ 1 University of Hradec Kralove, Hradec Kralove, Czech Republic; eva.simkova@uhk.cz; \\ martina.hoffmannova@uhk.cz \\ * Corresponding author: eva.simkova@uhk.cz
}

\begin{abstract}
Current business environment is being described as turbulent, or VUCA environment. VUCA is an acronym, which stands for Volatility, Uncertainty, Complexity and Ambiguity. The literature review shows that the approach to VUCA concept in the area of tourism and rural tourism is lagging behind other sectors. In the paper the basic principles and specifics of rural tourism are characterized. Problematic issues in rural tourism management are described in relation to VUCA environment. Using this knowledge and analysis of literature sources the VUCA Metrics of rural tourism in the Czech Republic was prepared. On the basis of VUCA Metrics the paper shows the way how to proceed with the preparation of methodological tools for the need of small companies of rural tourism. Firstly, to create the comprehensive theoretical view to this concept from the specific rural tourism point of view, and secondly to analyse the particular VUCA elements from the practical usage.
\end{abstract}

Keywords: rural tourism, business environment, VUCA concept, VUCA metrics

JEL Classification: Z3; M2; Q1

\section{Introduction}

Tourism is very important element of economic prosperity at the National Level. It plays very important role of regions development, mainly of rural areas and border areas (Binek et al., 2007). The rural areas development is not more connected only with agriculture support. The foreign sources show that the importance of agriculture as the main factor of development in rural areas in the West Europe and afterwards in the Middle Europe is in the last decades decreasing (Van der Ploeg, 2000). It leads to instability and unclear prospects mainly from the employment point of view for rural areas inhabitants. It is the reason of bigger support of non-agriculture activities to which belongs rural tourism.

Agriculture and most of the other businesses in rural areas are dependent on nature, and consuming natural resources. That actually raises difficulties to business-doing in those sectors. Yet, besides the above-mentioned dependence on natural resources, there are also other issues to be considered. Generally, business environment is currently very complex, turbulent, dynamic and very unpredictable (it shows the current situation affected by coronavirus pandemic). It is used with acronym VUCA, which stands for Volatility, Uncertainty, Complexity and Ambiguity. Acronym VUCA is used to describe conditions or situations in business environment, which can influence business operations. VUCA 
characteristics are not isolated but rather highly interrelated. As a result, any change in the business environment could have a far-reaching impact on an organization of rural business environment. Sustainability is, however, a key element of rural tourism. It is therefore necessary to examine these impacts on rural tourism itself, i.e. turbulence levels in rural tourism, VUCA features, and business reaction ability to upcoming changes.

\section{Theoretical Background}

\subsection{Approaches to Rural Tourism}

Although the concept of rural tourism is generally accepted, operational definitions are not consistent across countries (OECD, 1994). In general, it is the tourism which takes place in rural areas. Rural tourism is a multi-aspectual activity that includes diverse activities, e.g. educational, adventure, sports-recreational, gastronomic, hiking, cycling, skiing, mountain-climbing, hunting and fishing, exploration tours, travelling in search of art and heritage and many other products provided in the countryside.

Note: Rural tourism has many forms presented as its sub products. It is subsequently divided into agro tourism (tourism in farms), eco-agro tourism (tourism in ecological farms), village tourism (tourism in village settlements), cultural tourism (tourism with cultural heritage) and ecotourism (tourism in protected areas).

Rural tourism is intended for tourists, which have a principal motivation to stay in a village in contact with nature, to escape from the urban noise and civilization. The tourists often participate in agricultural activities, learn old crafts and customs. Rural tourism is considered as a sustainable form of tourism by keeping the natural and cultural heritage traditions, customs, handicrafts, natural attractions (e.g. Nosratabadi \& Drejeris, 2016). It relates to low population densities and open space (Dinis, 2011). Šimková (2013) stated that rural tourism is directly linked to the countryside (inhabited and uninhabited landscape with minimum human intervention), on which requirements of prevention in relation with sustainability are imposed. This means that all kinds of rural tourism should be sustainable, without negative impact on landscape and local community.

Note that it's also necessary to mention that the definition of a rural area is undoubtedly crucial for the concept of rural tourism. In order to determine rural areas, different criteria are used. From the simplest one - the population density to more complex, like economic features or combination of factors characterizing particular types of municipalities or rural regions (Maříková, 2006). In the Czech Republic, the criterion of number of inhabitants is most frequently used. According to this criterion, a municipality is considered as rural if there are less than 2,000 residents inhabiting it (MMR, 2006).

According to GNTO (2012, p. 7) rural tourism product is very complex and its quality is dependent on typical characteristics: "natural resources quality, guest structure, village structure, and cultural wealth". The importance of local rural resources as the most significant potential for rural tourism emphasises Lane (1994). Garrod et al. (2006) define rural resources as "rural capital". Irshad (2010) identifies rural tourism as the "country experience" that includes many attractions and activities that are provided to visitors in the 
form of entertainment or education. Jegdić et al. (2017) emphasizes sustainability of rural tourism that is defined through preservation of the countryside and natural environment, local culture and identity of local community and also creating balance between all activities in a rural area. Another specific feature of rural tourism, according to Ryglová et al. (2011), are lower requirements on infrastructure (roads, utility networks) and quite high business stability (revenues from tourism in rural areas go directly to businesses because they are provided by local subjects). According to Škrbić et al. (2015) the quality of rural tourism itself is attractiveness for tourists and therefore it is important to ensure the sustainable rural development with respecting rural areas specifics, preserving their authenticity and cultural values.

Rural tourism is believed to be a supportive element for the economic and social development of rural areas, because it is important source of income, creates new working opportunities, supports traditional hand-made manufacturing, folklore and other cultural traditions, represents rural life and heritage, protects the original landscape character, contributes to the use of rural areas' natural, cultural and historical potential, and revitalizes gastronomic traditions. Rural tourism is therefore one of the possibilities how to revive rural area and how to reduce its displacement (e.g. Ezeuduji, 2017; Figueiredo et al., 2014; McAreavey \& McDonagh, 2011).

\subsection{Business Environment and VUCA Concept}

In general, business environment is understood as a complex of external factors (PESTLE factors) or driving forces that influence business functioning. Understanding of substance and behaviour of external business environment is necessary for the long-term functioning of business as economic subject. Business environment is often divided into external and internal (company). In the paper business environment is understood mainly as external environment.

In 1965 Emery and Trist (1965) classified four models of external business environment. Since 1953 the environment has been evaluated as turbulent that is characterized by dynamics, mutual relationships among environment components and by interaction between organisations and surroundings. To the main characteristics of environmental turbulence belong: dynamism, uncertainty, unpredictability, unexpected, expanding, fluctuating, increased complexity, etc. Volberda and van Bruggen (1997) followed up the work of Emery and Trist and characterized the three main dimensions that simultaneously affect environmental turbulence: dynamism, complexity, (un)predictability of change.

Independently on the concept of environmental turbulence the VUCA concept was created. This concept was used for the first time in the army (Richard, 1997). VUCA is an acronym, which stands for Volatility, Uncertainty, Complexity and Ambiguity. The VUCA concept is composed of the factors those were already described before (e.g. Mack et al., 2016; Kail, 2010a, 2010b, 2010c, 2011):

Volatility is a degree of instability, frequency and number of changes; high volatility implies uncertainty and ambiguity (e.g. firms experience volatility thanks to unexpected event that disturb established routine). 
Uncertainty is a degree of unpredictability, or existence of multiple issues or factors, that are difficult to understand, lack of information (e.g. unpredictable competition - inability to define future competition levels, business trends and behaviour of other players; unpredictable market demand; unpredictable macro conditions etc.).

Complexity is a degree of mutual dependency, unclear causality, complexity consists of differences, which represents variability of interconnections.

Note that complexity relates to both external and internal business environment. In the both cases all relationship and mutual dependences expose. In the internal environment these are for example methodological procedure, decision-making processes, personal system, organisation and information system etc.

Ambiguity ambiguity of data and their interpretation (e.g. inability to make a decision).

In contrast to previous approaches, VUCA concept points out the necessity of understanding the mutual interaction of VUCA elements in context of concrete situations. VUCA concept broadens in the literature out that became standardized description of environment. Since 90's of the last century, the environment is referred to as VUCA environment often called as "VUCA world" (e.g. Schick et al., 2017; Wakelin-Theron et al., 2019). This term reflects rapidly changing and increasingly unstable business environment.

In the company practise in other economic sectors the VUCA concept is beginning to work into practical procedures of organizing and decision-making for different levels of management (e.g. Kambil, 2008; Lawrence, 2013; Mack et al., 2016; Sullivan, 2012).

It is important to realize that VUCA concept is not a method and does not provide the solution prepared to use but it is rather a set of measures for monitoring all four factors of environment that enables to map uncertain and complex situations influencing strategic company goals (e.g. Saleh \& Watson, 2017). Hence it is more suitable to speak about VUCA environment. It is therefore necessary to check the way of information collection and analysis of all VUCA factors for the strategic planning needs and decision-making. The information from VUCA environment became evident in the operational decision-making. From the information management point of view, it is possible to describe VUCA factors by the table (a detailed overview can be found in Table 1 below).

Simultaneously with the characteristic of VUCA elements are suggested the new measures how to react to each particular VUCA factor. For example Lawrence (2013) mentioned some antidote factors that can help to mitigate negative impact of VUCA. According to the author, volatility can be reduced by having a clear vision. Uncertainty can be reduced by understanding; complexity can be mitigated by clarity and ambiguity by agility.

\subsection{Application of the VUCA Environment in Rural Tourism Management}

Above-mentioned VUCA concept characteristics typically describe contemporary world which is very unstable from the political, economic, technological and climatic point of view and in connection with the current coronavirus crisis. It is therefore clear that VUCA concept could not avoid the application in tourism. 
Table 1. Characteristic of VUCA concept elements. Source: modified according to Bennett and Lemoine (2014); Liang et al. (2016); Mack et al. (2016)

\begin{tabular}{|l|l|l|}
\hline VUCA concept elements & Driving forces & Effects \\
\hline $\begin{array}{l}\text { Volatility } \\
\text { - requires the systematic } \\
\text { monitoring of external } \\
\text { environment }\end{array}$ & - dynamics and change character & - risks \\
\hline $\begin{array}{l}\text { Uncertainty } \\
\text { - lies in inability to exactly describe } \\
\text { the factors influencing the company } \\
\text { action in environment }\end{array}$ & - uncertain result & - market instability \\
\hline $\begin{array}{l}\text { Complexity } \\
\text { - increasing number of } \\
\text { environmental factors and their } \\
\text { mutual relationship }\end{array}$ & variables & - decision-making paralysis \\
\hline $\begin{array}{l}\text { Ambiguity } \\
\text { - previous experience doesn't help } \\
\text { to consider the current situation }\end{array}$ & - unclear relationships & - wrong structured problems
\end{tabular}

The literature research shows that the approach to VUCA concept in tourism and rural tourism lag behind in compare with other sectors.

In 2019 the international conference "Tourism in the VUCA world: towards the era of (ir)responsibility" (Vukadin \& Krešić, 2020) took place in Dubrovnik. Despite the VUCA term used in the conference title, in the whole conference proceedings collection there is no analysis how to use this concept at the practical level in tourism.

How difficult it is to cope with VUCA concept for the practical needs of tourism and rural tourism is shown in the article "Determining tourism graduate employability, knowledge, skills, and competencies in a VUCA world: Constructing a tourism employability model", again from 2019 (Wakelin-Theron et al., 2019). But in this article is no analysis applicability for the needs in tourism and rural tourism.

Other article called "Conservation and sustainable development in a VUCA world: the need for a systemic and ecosystem-based approach" (Schick et al., 2017) contains nothing what could be applicable to the managerial practice in tourism and rural tourism. Nevertheless, there is one positive. The article is interested in the particular VUCA elements at a general level and from the ecosystem point of view.

As already mentioned the literature review showed there are not many articles interested in tourism/rural tourism and VUCA concepts, the articles are more general and descriptive, and are not focused on practical usage in rural tourism management.

Rural tourism plays very important role in rural areas sustainability (economic, social, and ecological) as mentioned in the previous chapter. In context of VUCA environmental description it is important to bear in mind the interactions among economic, social and political processes and changes those influence the environment and are the base of rural 
tourism. Each of these processes can contain different VUCA elements with different intensity effect. The quality of rural tourism management lies in the ability to administrate the human, financial, infrastructure and nature sources with the target to ensure the attractiveness of natural environment when respecting the specificity of rural areas. The natural sources are not often the priority of rural tourism management despite they are the pillars of rural tourism and influence the attractiveness of rural locality.

There is the question: How VUCA factors could be reflected in rural tourism business environment? It is important to realise that rural tourism businesses are the most frequently organized as small family businesses (Jegdić et al., 2017) and are often connected with the ability to react fast and effectively to the surroundings changes. The reality is often different. The small companies (which means the rural tourism businesses too) are in the contemporary turbulent environment very often vulnerable.

\section{Methodology}

Above-mentioned, VUCA concept globally describes increasingly unstable and rapidly changing business environment. However there is lack of information how firms or their leaders should react to some of the VUCA factors. Growing non-stability and non-predictability, however, does not necessarily carry along potential disasters. In fact, it can also mean challenges to organizations.

Because there are not many scientific articles concerning VUCA concept in rural tourism, there are three main aims of the paper:

1. to describe the basic principles of rural tourism and the problematic issues in rural tourism management,

2. to use VUCA Metrics in rural tourism,

3. to suggest that the academic community should deal with this concept more systematically so that it can be commonly used in rural tourism management.

On the example of VUCA Metrics the paper shows how to proceed with the preparation of methodological tools for needs of small rural tourism businesses. To the rural tourism environment analyse in VUCA context the Bennett and Lemoine's VUCA Metrics was used. It is about schematic interpretation of VUCA concept published in the Harvard Business Review in 2014 in contribution called "What VUCA Really Means for You" (Bennett \& Lemoine, 2014). The particular VUCA categories are characterized according to situational knowledge ("How much do you know about the situation?"), and according to the abilities to anticipate the result of specific action ("How well can you predict the results of your actions?").

According to the authors, the VUCA is connection of four different challenges those require four different types of answers. The authors mention the instructions how to identify and react to each of four VUCA categories: approach to Volatility lies in preparedness and reserve creation; approach to Uncertainty is to invest to information - their collecting and interpretation; Complexity can solve by restructuring processes; Ambiguity solving lies in 
understanding the cause and effect, creation of experiments etc. Using this knowledge and analysing other sources the VUCA Metrics of rural tourism was prepared.

\section{Results}

\subsection{Rural Tourism Management in Turbulent Environment}

It is generally accepted that management represents leadership, anticipation, organization and coordination of sources (in case of rural tourism it is primarily people, natural resources, living style, local habits) in order to achieve maximum effectiveness in the use of such sources without negative impact on the environment. Specific features of rural tourism then lays specific requirements on the management and problem solving.

In rural tourism, businesses are represented primarily by small and medium size companies, because these can better represent character of the destination (rural locality) and offer personalized rural tourism products in very specific market conditions (niche markets). However, at the same time they are exposed to:

- limited resources (finance, know-how),

- lack of qualified personnel (management, financial management, marketing, etc.),

- specific barriers, primarily due to its business size, such as marketing costs,

- limitations in tourism products design.

Rural tourism management weakness causes other factors too (Srb, 2002; Šimková, 2014):

- deficiency in tourism management system (inefficient organisation structure of tourism),

- lack of coordination and cooperation in tourism,

- low efficiency of groups of interest,

- low attendance of local community,

- limited managerial abilities participating sides.

Based on the characteristics and definitions (presented in chapter 2.1) it can be summarized basic principles of rural tourism and also its main specifics:

1. the primary enticement of rural tourism is attractiveness of the nature,

2. rural activities and services are sorted and organized by main characteristics of rural areas,

3. organization and economics of rural tourism is dependent especially on effective cooperation between stakeholders,

4. seasonality effect of rural tourism,

5. labour quality requirements,

6. business unpredictability,

7. relatively risky business conditions with low profitability,

8. very specific infrastructure.

Due to specific features of rural tourism in combination of the character of small and medium size businesses, there are the following risk-bearing areas in rural tourism management:

$\left.\mathrm{Ad}_{1}\right)$ nature attractiveness: This is the key question of rural tourism management: How to effectively manage rural tourism while preserving nature environment as the primary 
attractiveness of rural tourism, i.e. whether purely business oriented development, or with respect to sustainability development?

$\mathrm{Ad}_{2}$ ) characteristics of rural areas: it relates with the concept of sustainable livelihoods that emphasizes development of needs and priorities of local people;

$\mathrm{Ad}_{3}$ ) cooperation between stakeholders: involvement and coordination of stakeholders in cooperation or networking;

$\mathrm{Ad}_{4}$ ) seasonality of rural tourism: seasonality problems primarily include issues such as seasonal demand for workers at one side and seasonal availability of workers on the other, negative impact of rural tourism activities on the environment coming from seasonal visit peaks (waste, damages on infrastructure, wildlife disturbance), excessive visit rate can cause increased stress on local people, waste-related problems, water supply problems;

$\left.\mathrm{Ad}_{5}\right)$ labour quality requirements: specific skills and know-how requirements on rural tourism entrepreneurs, workforce seasonality;

Ad6) business unpredictability: large sale of market segments practically involved in rural tourism activities;

Ad7) risky business conditions - low profitability: lack of financial sources available for CAPEX investment;

Ad8) specific infrastructure of rural tourism: development of tourism infrastructure (agriculture buildings, farms, accommodation) can lead to loss of land (for agriculture purposes) and loss of rural area characteristics.

\subsection{VUCA Metrics of Rural Tourism in the Czech Republic}

Based on a thorough review of the relevant literature, and determination basic principles of rural tourism and the problematic issues in rural tourism management the VUCA Metrics was created (Figure 1).

\section{Discussion}

Results presented in Figure 1 indicate that although all VUCA categories are presented, uncertainty and complexity are most aware of by businesses in rural tourism in the Czech Republic:

Uncertainty in connection with rural tourism's business environment in the Czech Republic lies in the lack of predictability of changes that is caused mainly by ambiguity in vision and tourism conception of the Czech Republic. These problems are deepened by the lack of specific skills and know-how requirements on rural tourism entrepreneurs (management, marketing, legislative, communication skills, risk management, knowledge about environment changes etc.). Due to inherited uncertainty from seasonality effect of rural tourism and relatively low business profitability in general is apparent mainly in agritourism with the dilemma of investments to agriculture production or agritourism services. 


\begin{tabular}{|c|c|c|}
\hline+ & Complexity & Volatility \\
\hline 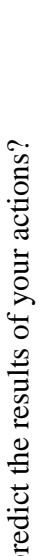 & 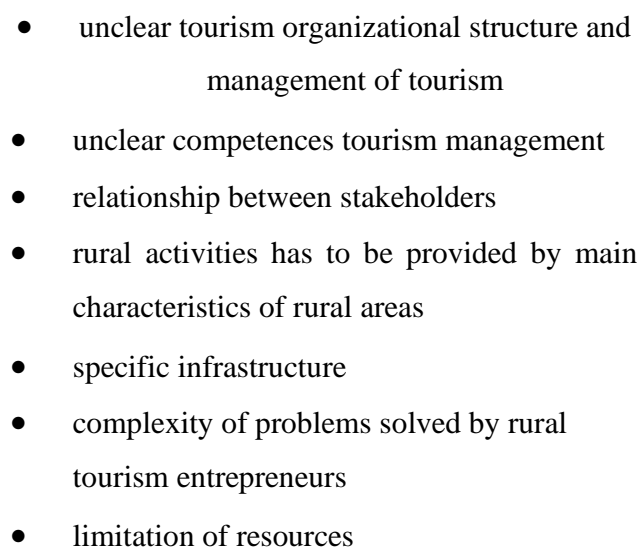 & 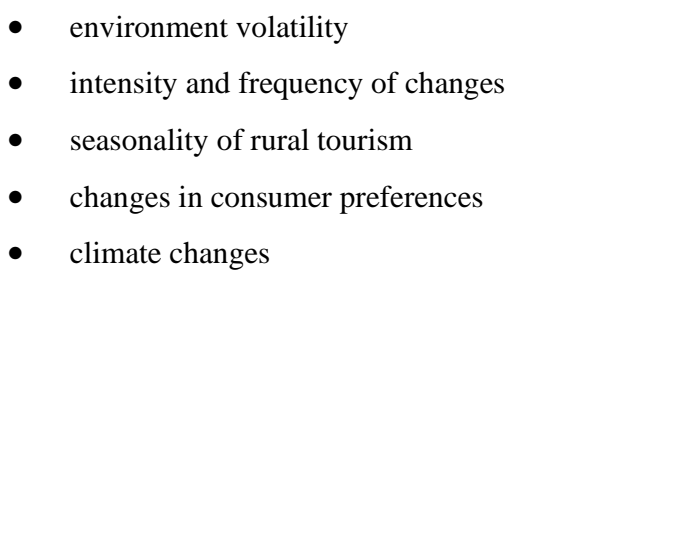 \\
\hline $\bar{\Xi}$ & Ambiguity & Uncertainty \\
\hline $\begin{array}{l}\text { ]ี } \\
\overline{0} \\
0 \\
3 \\
3 \\
0 \\
0\end{array}$ & $\begin{array}{l}\text { - } \\
\text { - } \\
\text { regionbiguity and incompleteness of policy of } \\
\text { ambiguity in tax legislation and } \\
\text { tourism-related legislation } \\
\text { - } \quad \text { business unpredictability } \\
\text { - limitations in tourism products design }\end{array}$ & $\begin{array}{l}\text { - lack of clear tourism conception } \\
\text { - } l \text { lack of environmentally friendly tourism support } \\
\text { - } \quad \text { underestimation of tourism sustainability issues } \\
\text { - } \quad \text { labour quality requirements } \\
\text { - } \quad \text { relatively risky business conditions } \\
\text { - low profitability business } \\
\text { - } \\
\text { predictability of changes }\end{array}$ \\
\hline & \multicolumn{2}{|c|}{$\Longrightarrow$} \\
\hline
\end{tabular}

Figure 1. VUCA Metrics of rural tourism in the Czech Republic (authors' own research using Bennett and Lemoine (2014))

The biggest problem of Complexity is in the number of elements and mutual interconnections between stakeholders. It is connected mainly with non-existence of generally accepted tourism organization structure that resulted in unclear tourism organization structure and management of tourism and unclear competences of national, regional and local levels of tourism management. The involvement and coordination of stakeholders in cooperation or networking is problematic too. As a general rule the stakeholders in a local destination can manage rural tourism development. This will provide sustainability and income in rural communities. Local people are some of the most important stakeholders in rural tourism (stakeholders' roles in a destination development present e.g. Ezeuduji, 2017; Saxena, 2005). Complexity of business environment in rural tourism is connected with limitation of resources (finance, knowledge).

In general Volatility deals with instability and unexpected changes in macro and micro environment (changes in economic, social, technological, political, legislative environment), their intensity and frequency, that is in effect for rural tourism in the Czech Republic. Volatility also deals with seasonality of rural tourism that includes seasonal demand for workers, availability of workers, seasonal visit peaks causing increased stress on local people, waste-related problems, and water supply problems. There is also seasonality effect of rural tourism similar to agro tourism (haymaking, crop harvesting). 
Ambiguity (same like Volatility) is no so frequent VUCA parameter; even though it belongs to the factors those make the identification of threats and opportunities difficult. In connection with rural tourism business environment in the Czech Republic the main problem is esp. ambiguity and incompleteness of regional development policy and rural areas support. Regarding business unpredictability there is a conflict between general market segmentation and providing services to individual segments. Moreover, the entrepreneurs are limited in tourism products design - businesses and must always take the environment protection, places of historic values, resources, culture and customs of rural areas into account.

\section{Conclusions}

In general, small companies are often considered as very flexible with the ability to effectively in time react to changes but this prerequisite does not describe to which type of changes the small companies are resistant. Paradoxically, the small companies in rural tourism are more vulnerable and fragile towards to external environment represented by VUCA concept. It was demonstrated on the research by which the VUCA parameters were identified. By summarisation and simplification, it is possible to define the key factors of "VUCA World": clearly define strategy, team work, system communication, anticipation and risk management.

In rural tourism predominate small and medium enterprises, therefore it is important to bear in mind that the viability of these businesses depends on ability to identify the trends and opportunities in external environment. Unfortunately, the small rural tourism enterprises often do not monitor the external environment either because of lack of management skills or due to organisational and financial reasons. The VUCA concept is primary related to firm management and abilities to organize and decide. Changes in business environment often lead to resources destruction, stiffness and inflexibility. However, the VUCA concept requires a deeper understanding of how to process information and how to monitor an organization's environment.

The literature review showed the VUCA concept is not adapted to practical use in rural tourism which could be task for academic sphere. Firstly, to create the comprehensive theoretical view to this concept from the specific tourism/rural tourism point of view, and secondly to analyse the particular VUCA elements from the practical usage.

There are as well some questions and tasks for academic sphere for the needs of future praxis:

1. How could the VUCA factors be reflected in rural tourism business environment?

2. How to ensure that even small businesses in rural tourism will be able to work with VUCA concept?

With regard to the fact that the concept of the VUCA environment is not known in practice, it is appropriate to approach the practical application mainly on the basis of well-processed theoretical data for individual actors of rural tourism, as the parameters of the VUCA environment may be perceived differently. This means using traditional 
management practices such as risk management, marketing analysis of the environment, business continuity management and change management.

In conclusion it can be stated that response proposition for different situations of VUCA environment will be the subject of authors' further research.

Acknowledgments: This article is financial supported by Faculty of Education within the project to support the scientific team for tourism, project $n$. 11 .

\section{References}

Bennett, N., \& Lemoine, G. J. (2014). What VUCA Really Means for You. Harvard Business Review, 92(1/2), 27. Binek, J. et al. (2007). Venkovský prostor a jeho oživení. Georgetown.

Dinis, A. (2011). Tourism, niche strategy and networks as factor for both entrepreneurship and rural sustainability. In IX Rural Entrepreneurship Conference: A sustainable rural?

Emery, F. E., \& Trist, E. L. (1965). The Causal Texture of Organizational Environments. Human Relations, 18(1), 21-32. https://doi.org/10.1177/001872676501800103

Ezeuduji, I. O. (2017). Change management for sub-Saharan Africa's rural tourism development. Current Issues in Tourism, 20(9), 946-959. https://doi.org/10.1080/13683500.2014.946892

Figueiredo, E., Kastenholz, E., \& Pinho, C. (2014). Living in a Rural Tourism Destination - Exploring the Views of Local Communities. Revista Portuguesa de Estudos Regionais, 36(2). 3-12. http://www.apdr.pt/siterper/numeros/RPER36/36.1.pdf

Garrod, B., Wornell, R., \& Youell, R. (2006). Re-conceptualising rural resources as countryside capital: The case of rural tourism. Journal of Rural Studies, 22(1), 117-128. http://course.sdu.edu.cn/G2S/eWebEditor/uploadfile/20130509154805009.pdf

GNTO/Greek National Tourism Organisation. (2012). How to establish a rural tourism business. (A deliverable in the framework of the E.U. Program). Athens.

http://www.eot.gr/sites/default/files/files_article/12_steps_to_establish_a_rural_tourism_business.pdf

Irshad, H. (2010). Rural Tourism - An Overview. Government of Alberta, Agriculture and Rural Development. http://www1.agric.gov.ab.ca/\$Department/deptdocs.nsf/all/csi13476/\$FILE/Rural-Tourism.pdf

Jegdić, V., Škrbić, I., \& Milošević, S. (2017). Models of entrepreneurship development in rural tourism destinations in Vojvodina. Economics and Agiculture, 64(1), 221-237. https://doi.org/10.5937/ekoPolj1701221J

Kail, E.G. (2010a). Leading in a VUCA environment: $V$ is for volatility. Harvard Business Review. https://hbr.org/2010/11/leading-in-a-vuca-environment

Kail, E.G. (2010b). Leading in a VUCA environment: $U$ is for uncertainty. Harvard Business Review. https://hbr.org/2010/11/leading-in-a-vuca-environment-1

Kail, E.G. (2010c). Leading effectively in a VUCA environment: $C$ is for complexity. Harvard Business Review. https://hbr.org/2010/12/leading-effectively-in-a-vuca

Kail, E.G. (2011). Leading effectively in a VUCA environment: $A$ is for ambiguity. Harvard Business Review. https://hbr.org/2011/01/leading-effectively-in-a-vuca-1

Kambil, A. (2008). Synchronization: moving beyond re-engineering. Journal of Business Strategy, 29(3), 51-54. https://doi.org/10.1108/02756660810873236

Lane, B. (1994). What is rural tourism? Journal of Sustainable Tourism, 2(1-2), 7-21. https://doi.org/10.1080/09669589409510680

Lawrence, K. (2013). Developing Leaders in a VUCA Environment. UNC Executive Development. https://www.emergingrnleader.com/wp-content/uploads/2013/02/developing-leaders-in-a-vuca-environme nt.pdf

Liang, F. S., Lee, L., \& Sang, C. N. (2016). Risk Management in a VUCA Environment. https://www2.deloitte.com/content/dam/Deloitte/sg/Documents/risk/sea-risk-management-in-vuca-enviro nment-noexp.pdf

Mack, O., Khare, A., Krämer, A., \& Burgartz, T. (Eds.). (2016). Managing in a VUCA World. Switzerland: Springer. Mař́k ková, P. (2006). Where is the Countryside? (Setting the Borders of Countryside in Conditions of the Czech Republic). In Majerová, V. (Ed.), Proceedings of the International Conference Countryside - Our World (pp. 432-444). PEF ČZU. 
McAreavey, R., \& McDonagh, J. (2011). Sustainable Rural Tourism: Lessons for Rural Development. Sociologia Ruralis, 51(2), 175-194.

MMR. (2006). Strategie regionálního rozvoje České republiky na roky 2007-2013. http://www.mmr.cz/cs/Podpora-regionu-a-cestovni-ruch/Regionalni-politika/Koncepce-Strategie/Strategieregionalniho-rozvoje-Ceske-republiky-na.

Nosratabadi, S., \& Drejeris, R. (2016). Innovations in Rural Tourism Business Model. International Journal of Business and Management Invention, 5(4), 60-66.

OECD. (1994). Tourism policy and international tourism in OECD countries 1991-1992. Special feature: Tourism strategies and rural development. Paris: OECD.

Richard, J. S. (1997). The Learning Army: Approaching the 21st Century as a Learning Organization. Carlisle Barracks, PA: U.S. Army War College. 34 p. https://apps.dtic.mil/dtic/tr/fulltext/u2/a327188.pdf

Ryglová, K., Burian, M., \& Vajčnerová, I. (2011). Cestovní ruch - podnikatelské principy a př́ležitosti v praxis. Grada Publishing.

Saleh, A., \& Watson, R. (2017). Business Excellence in a volatile, uncertain, complex and ambiguous environment (BEVUCA). The TQM Journal, 29(5).

Saxena, G. (2005). Relationships, networks and the learning regions: case evidence from the Peak District National Park. Tourism Management, 26(2), 277-289. https://doi.org/10.1016/j.tourman.2003.11.013

Schick, A., Hobson, P. R., \& Ibisch, P. L. (2017). Conservation and sustainable development in a VUCA world: the need for a systemic and ecosystem-based approach. Ecosystem Health and Sustainability, 3(4), 1-12. https://doi.org/10.1002/ehs2.1267

Srb, J. (2002). Návrh modelu řízení cestovního ruchu v turistické destinaci Český ráj. www.cesky-raj.info/filemanager/files/file.php?file=1214

Sullivan, J. (2012). VUCA: the New Normal for Talent Management and Workforce Planning. https://www.ere.net/vuca-the-new-normal-for-talent-management-and-workforce-planning/

Šimková, E. (2013). Sustainability in Tourism and Rural Areas. Gaudeamus.

Šimková, E. (2014). Analysis of Tourism and Agro tourism Management in the Czech Republic and Austria. Acta Univ. Agric. Silvic. Mendelianae Brun., 62(4), 811-824. https://doi.org/10.11118/actaun201462040811

Škrbić, I., Jegdić, V., Milošević, S., \& Tomka, D. (2015). Development of Sremski Karlovci wine tourism and integration in the regional tourism offer. Economics of Agriculture, 62(1), 229-244. https://doi.org/10.5937/ekoPolj1501229S

Van der Ploeg, D. J. (2000). Revitalizing Agriculture: Farming Economically as Starting Ground for Rural Development. Sociologia Ruralis, 40(4), 497-511. https://doi.org/10.1111/1467-9523.00163

Volberda, H. W., \& van Bruggen, G. H. (1997). Environmental Turbulence: A look into its Dimensionality. In ERIM (Electronic) Books and Chapters (pp. 137-145). https://repub.eur.nl/pub/6438

Vukadin, I. M., \& Krešić, D. (Eds.). (2020). Tourism in the VUCA world: towards the era of (ir)responsibility. International Tourism Conference, Dubrovnik.

Wakelin-Theron, N., Ukpere, W. I., \& Spowart, J. (2019). Determining tourism graduate employability, knowledge, skills, and competencies in a VUCA world: Constructing a tourism employability model. Journal of Hospitality, Tourism and Leisure, 8(3), 1-18. 